\title{
ЯПОНЫ ДИПЛОМАТ АЛБА
}

\author{
П.Мягмардорж. \\ ХҮмүҮнлэгийн Ухааны Их Сургуулийн \\ Олон Улсын Харилцааны тэнхимийн эрхлэгч.
}

\section{Японы дипломат албаны түүх}

Японы дипломат ажиллагаа нь Япон улс МЭ-ний 607 онд Хятадын Сүй улсад анхны элчин сайдаа илгээснээр эхэлсэн хэмээн түүхэн судар бичигт тэмдэглэн үлдсэн байдаг. Мөн тухайн үеийн Хятадын Сүй болон Тан улсад Японоос элч төлөөлөгчид явуулж байсан ажээ. Харин 894 оноос хойш Японоос элч төлөөлөгчдийг Тан улс руу явуулахыг зогсоосноос эх газрын соёл Японд нэвтрэн ирэх явдал нь хумигдав. Үүнээс хойш олон зууны турш Япон улс идэвхитэй гадаад харилцаа явуулалгүйгээр дундад зууны сүүл үе хүрчээ.

Европчууд анх 16-р зууны дундуур Японд хүрэлцэн ирсэн бөгөөд 1543 онд Португалийн, 1584 онд Испанийн худалдаачид ирсэн бол 1549 оноос Европын хар лам нар ирж Христосын шашныг дэлгэрүүлэх оролдлогыг хийж байжээ. Харин Японы тал 1613 онд Испанид өөрийн элчин сайдаа илгээснээр Өрнөдийн орнуудтай албан ёсны харилцаа тогтоох эхлэл тавигдсан хэмээн үздэг. Ийнхүү Европын улсуудын Японтой харилцах харилцаа идэвхижсэнээр Япон улс дэлхийн худалдаа эдийн засгийн харилцаанд оролцох боломж нээгдсэн байна. Гэвч Өрнөдийн гүрнүүдийн Японы арлуудыг өөрсдийн мэдэлд оруулах гэсэн санаархал нь Япон улс өөрийн газар нутгаас гадаад иргэдийг хөөн гаргах шалтгаан болжээ.Токүгава овгийн Шёогүн Хидэдата 1613 онд Христос шашныг хориглон Португали, Испани хар лам нарыг нутгаасаа хөөн гаргаж, 1630-аад оны эхээр худалдааны лиценз авснаас бусад гадаадын онгоц орж ирэхийг хоригложээ. Улмаар 17-р зууны 40-өөд оноос эхлэн 200 гаруй жил гадаад ертөнцөөс тусгаарлагдан Японы гадаад бодлого, дипломат ажиллагаа зогсонги байдалд орсон байна.

1854 онд Америкчууд тэнгисийн цэргийн тусламжтайгаар Японтой энх тайван, худалдаа эдийн засаг болон далайн тээврийн гэрээг тус тус байгуулсан бөгөөд Их Британи, Франц, Нидерланд, Орос зэрэг улсууд Японтой худалдаа, эдийн засгийн харилцаагаа эрчимтэй хөгжүүлж эхэлжээ. Гэвч энэ үед Японд тогтож байсан Бакүфү засаглалын улмаас бие даасан дипломат алба байгуулагдах боломжгүй байжээ. 19-р зууны дунд үеэс эхэлсэн энэхүу засаглалыг эсэргүүцсэн бослого нь Японы өнцөг булан бүрт дэгдэж 1867 он гэхэд Бакүфү засаглал унах нь тодорхой болов. 1867 онд цэргийн дарангуйллын засаглалд өөрчлөлт орсноор Японы дипломат алба байгуулагдах үндэс суурь тавигджээ.

Мэйжигийн шинэчлэлийн үр дүнд 1868 онд 11 их, бага зөвлөхүүдээс бүрдсэн "Гадаад бодлогын асуудал эрхэлсэн алба" бий болж, тэргүүнээр ахлах зөвлөх М.Ямашина томилогдон ажиллаж байлаа. 1869 онд 6 яам байгуулагдсаны нэг нь Гадаад хэргийн яам байсан юм.

1870-1874 оны хооронд Их Британи, Франц, Прусс, Америк, Австри, Хятад зэрэг улсуудад төлөөлөгчийн газруудаа байгуулсан бол 1914 онд Америк, Орос, Франц, Их Британи, Итали дахь төлөөлөгчийн газруудаа элчин сайдын яам болгон өөрчилжээ.

1879 онд Гадаад хэргийн яамнаас баталсан журмын дагуу газар хэлтэсүүд бий болж газрыг зөвлөхүүд (зиё), хэлтсийг нарийн бичгийн дарга (рокү) нар толгойлох болсон бөгөөд ГХЯ нь дараах газруудаас бүрдэж байв. Үүнд:

1. Европын улсуудтай харилцах 1-р газар

2. Ази Америкийн улсуудтай харилцах 2-р газар

3. Зохион байгуулах газар (баримт бичгийн хэрэг эрхлэх)

4. Орчуулгын газар 
5. $\quad$ Гэрээ хэлэлцээрийн газар

6. Нийтлэг асуудал эрхэлсэн газар

Ито Хиробүми Германы засгийн газрын бүтцээс санаа авч 1885 онд 11 яамнаас бүрдсэн Японы засгийн газрын кабинетийг Мэйжигийн зарлигаар шинэчлэн байгуулжээ. Энэ шинэ ЗГ-ын бүрэлдэхүүнд Гадаад Хэргийн Яам багтаж байсан бөгөөд анхны сайдаар нь Иноүэ Каору томилогдон ажиллаж байв. ГХЯ-ны эхний жилүүдэд гол албан тушаалууд болон хилийн чанадад суух төлөөлөгчийн газрын тэргүүнээр улс төрийн томилгооныхон ажилладаг байсан бол аажмаар дипломат албан тушаалд дипломат ажиллагааны туршлагатай хүмүүсийг сонгон ажиллуулах болсоны зэрэгцээ 1893 оноос эхлэн ГХЯ-нд ажиллах хүмүүсээс тусгай шалгалт авдаг болжээ.

19-р зууны сүүлч үеэс эхлэн Японы гадаад бодлогод колоний эзэмшилээ өргөжүүлэх, өөрийн нөлөөг Зүүн болон Зүүн өмнөд Азид тэлэх бодлого гол байр суурь эзлэх болсон ба 1889 оны 2 сарын 11-нд батлагдсан Мэйжигийн үндсэн хуулийн үр дүнд Японы гадаад бодлогын шийдвэр гаргалтад эзэн хаан гол эрх мэдэлтэй болж хувирсан бөгөөд ГХЯ-ны эрх үүрэг багассан ажээ. Засгийн газар дахь Цэргийн яамны байр суурь колоний бодлоготой холбоотойгоор өсч тэдний эзэн хаанд үзүүлэх нөлөө нэмэгдсэнээр гадаад харилцааны салбарт цэргийнхэн голлох болж 1930-аад оноос эхлэн генерал, адмирал зэрэг цэргийн цол хэргэмтэй хүмүүсийг элчин сайдаар томилох болсон байна.

1895 оны Чин улстай, 1904 оны Хаант Оростой хийсэн дайнуудад Япон улс ялалт байгуулж, “Симоносекийн гэрээ”, Портсмут хотод байгуулсан “Орос-Японы энх тайвны гэрээ”- гээр өөрийн Зүүн Ази төдийгүй олон улсын харилцаан дахь байр сууриа бэхжүүлж чаджээ.

1912 оны 7-р сарын 30-нд эзэн хаан Мэйжи нас барж, түүний оронд Ёшихито хаан ширээнд сууснаар шинэ эрин буюу Тайшёо-гийн эрин үе эхэлж Японы гадаад бодлого дахь цэргийнхэний эрх мэдэл улам нэмэгдсэн юм.

Японы дипломат албаны түүхэнд гарсан нэг томоохон зүйл нь дэлхийн 1-р дайны дараачаас эхлэн хилийн чанадад суугаа иргэдийнхээ ашиг сонирхолыг хамгаалах зорилгоор консулын байгууллагуудыг олноор нээх болсон явдал юм.

1940 онд гадаад хэргийн сайдаар Ё.Мацүока томилогдсон бөгөөд тэрээр Ром- БерлинТокиогийн 3-ын холбоо бий болгохыг дэмжиж байсны зэрэгцээ түүний удирдлаган дор Японы ГХЯ Зүүн Азид “Шинэ дэг журам” тогтоох тухай саналыг боловсруулсан ба энэхүҮ саналд 1-р шатанд Хятад, Тайланд, Малайз, Филиппин, Шинэ Гвиней, 2-р шатанд Австрали, Шинэ Зеланд, Бирм, Зүүн Энэтхэгийг түрэмгийлэн эзлэх төлөвлөгөө агуулагдаж байжээ. Гэвч дэлхийн 2-р дайнд Япон улс ялагдсанаар 1945-1952 оныг хүртэл Япон улс бие даасан гадаад бодлого явуулах эрхгүй болж, Японы хилийн чанад дахь төлөөлөгчийн газрууд татан буугджээ.

1947 онд батлагдсан шинэ үндсэн хуулийн 9-р зүйлд “Шударга ёс журамд түшиглэсэн олон улсын энх тайвны төлөө чин сэтгэлээсээ эрмэлзэн, Японы ард түмэн дайн хийх үндэстний бүрэн эрхээсээ болон улс хоорондын маргаантай асуудлыг шийдвэрлэхэд зэвсэгт хүчнийг ашиглах ба заналхийх явдлаас үүрд татгалзана. Энэхүу зорилго эрмэлзлэлээ хэрэгжүүлэхийн тулд хуурай замын, тэнгисийн, агаарын цэрэг болон дайны бусад хүчийг хэзээ ч байлгахгүй. Улс орны дайн байлдаан хийх эрхийг хүлээн зөвшөөрөхгүй." хэмээн заасан байдаг ажээ.

1951 оны 9 сарын 8-нд гарын үсэг зурж, 1952 оны 4 сарын 28-нд хүчин төгөлдөр болсон Сан-Францискогийн гэрээгээр Япон улс төрийн бүрэн эрхээ сэргээж, дотоод болон гадаад бодлогоо бие даан явуулах эрхтэй болжээ.

1951 оны 12 сарын 1-ны Гадаад Хэргийн Яамыг байгуулах тухай, 1952 оны 3 сарын 31ний дипломат албан хаагчдын тухай хуулиуд батлагдсанаар Японы орчин цагийн дипломат албаны эрх зүйн үндэс тавигдсан юм.

Японы гадаад бодлого идэвхижснээр ГХЯ-ны бүтэц, зохион байгуулалт өргөжиж, 1955 онд Цагаачлалын асуудал эрхлэх газар, 1957 онд Америкийн газар болон Европ, Далайн 
орнуудын газар, 1958 онд НҮБ-ын газар, 1961 онд Ойрхи Дорнод, Африкийн газар, 1965 онд Төв болон Өмнөд Африкийн газар тус тус байгуулагджээ.

2-р дайны дараах Японы гадаад бодлогод АНУ-тай харилцах асуудал гол байр суурь эзэлж байсны зэрэгцээ эдийн засгийн дипломат ажиллагаа Японы ГХЯ-ны үндсэн үүргүүдийн нэг болсон билээ. Японы ГХЯ энэ үед туршлагатай дипломат боловсон хүчний нөөцөөр дутмаг байсан бөгөөд 1950-аад оны дунд үе хүртэл Америкийн зөвлөхүүд ГХЯ-нд ажиллаж байжээ.

1950-аад оны сүүлчээс Японы эдийн засгийн хөгжил түргэсч 1960-аад оны сүүлч гэхэд Их Британи, Франц, ХБНГУ-ыг гүйцэж түрүүлсэн бөгөөд Япон улс өөрийн эдийн засгийн хүч чадавхид тулгуурлан олон улсын харилцаанд тодорхой байр суурь эзлэх зорилт дэвшүүлжээ. Энэ зорилтыг хэрэгжүүлэхийн тулд АНУ-аaс хараат байдлаа сулруулж бүх улстай найрсаг харилцаа тогтооход чиглэсэн “олон талт дипломат ажиллагаа" явуулж эхэлсэн байна.

Японы дотоодын хууль тогтоомжийн дагуу төрийн байгууллагуудаас зөвхөн ГХЯ гадаадын төрийн байгууллагуудтай гэрээ хэлэлцээр байгуулах эрхтэй байлаа. 1996 оны байдлаар Японы төр засгийн төв байгууллагын нийт ажилтны тоо 1 сая 160 мянга гаруй байснаас ГХЯ 4.7 мянган хүнтэй байсан нь нийт төр засгийн төв байгууллагын ажилтны 0.9 хувь болдог байжээ.

1999 оны 7 сарын 16-нд Японы ГХЯ-ны тухай хууль шинэчлэн батлагдсан бөгөөд энэхүY хууль нь Японы эдийн засгийн их гүрний статусыг илэрхийлсэн, гадаад бодлогын үйл ажиллагааг илүү их прагматик шинжтэйгээр хөгжүүлэх бололцоог олгосон хууль болжээ. Шинэчилсэн хууль нь 4 бүлэг 13 зүйлээс бүрддэг бөгөөд 1-p бүлэг нь өмнөх хуулийн нэгэн адил хуулийн зорилготой холбоотой нийтлэг үндэслэлийг тусгасан бол 2-р бүлэг нь яамны үндсэн үүрэг, зорилтуудыг тодруулжээ. 3-р бүлэгт ГХЯ-ны бүтэц зохион байгуулалтын талаар зааж өгсөн бөгөөд сайдаас гадна эдийн засгийн болон улс төрийн асуудал эрхэлсэн 2 орлогч сайд, ёслолын дарга тус тус ажиллахаар зааж өгсөн. Мөн энэ бүлэгт Японы хилийн чанад дахь төлөөлөгчийн газруудыг тодорхойлж, эдгээр нь Элчин сайдын яам, Төлөөлөгчийн газар, Ерөнхий консулын газар, Консулын газар, Засгийн газрын төлөөлөгч байхаар болсон. 4-р бүлэгт (13-р зүйлд) өргөмжит ерөнхий консул болон өргөмжит консул нарын талаар зааж тэдгээрийг Японы ГХЯ томилж байхаар болжээ.

Японы ГХЯ нь гадаад улсуудтай харилцах асуудлыг эрхэлдэг гол байгууллага бөгөөд дээр өгүүлсэнчлэн улсын гадаад бодлогыг хэрэгжүүлэх, гадаад эдийн засгийн дипломат ажиллагааг явуулах, бусад улсуудтай соёл, хүмүүнлэгийн болон бусад салбар дахь харилцааг хөгжүүлэх гэх мэт үндсэн үүргүүд энэ яаманд ноогддог. Японы хууль тогтоомжид заасны дагуу Японы олон улсын чанартай гэрээ хэлэлцээрүүдэд (улс төрийн, эдийн засгийн, шинжлэх ухаан техникийн, соёл, хүмүүнлэгийн, хүрээлэн буй орчны гэх мэт) улсаа төлөөлөх эрхтэй цорын ганц яам нь ГХЯ юм.

1885 онд ГХЯ-ыг шинэчлэн байгуулан анхны сайдаар ажиллаж байсан Иноүэ Каорүгээс хойш өнөөдрийг хүртэл 104 сайд ГХЯ-ыг толгойлж байжээ. 2011 оны 3-р сарын 9-нд Мацүмото Такэаки (Японы анхны ерөнхий сайд бөгөөд 2-дахь гадаад хэргийн сайд Ито Хиробүмигийн жич хүү) гадаад хэргийн сайдаар ажиллаж байна.

Японы дипломат албаны онцлог, өнөөгийн бүтэц, зохион байгуулалт

Японы хуууль тогтоомж ёсоор Гадаад Хэргийн Яамны үндсэн үүрэг нь:

1. Гадаад бодлогыг төлөвлөж хэрэгжүүлэх;

2. Өөрийн улсын дипломат ба консулын төлөөлөгчийн газруудыг удирдах;

3. Олон улсын гэрээ, хэлэлцээр байгуулах;

4. Олон улсын байгууллагын ажил, хурал зөвлөгөөнд оролцох; 
5. Гадаад улс орныг судлах;

6. Олон улсын харилцааны асуудлаар Засгийн газрыг мэдээллээр хангах;

7. Гадаад улс оронтой эдийн засаг соёлын харилцаа барих;

8. Хилийн чанадад байгаa Японы иргэдийн эрх ашгийг хамгаалахад оршино.

Японы ГХЯ нь төрийн албанд хэрэглэгддэг 3 шатлал бүхий бүтэцтэй бөгөөд эдгээр нь: Сайд - товчоо (bureau) буюу газар (department) - хэлтэс (division) зэрэг болно. Сайдын зэрэг нь улс төрийн албан тушаалд тооцогддог бөгөөд учир нь сүүлийн жилүүдэд мэргэжлийн дипломатчдаас бус сонгуульд ялалт байгуулсан намын гишүүдээс уг албан тушаалд томилдог практик тогтсон байна. Сайд нь гадаад бодлогын асуудалтай холбоотой Засгийн газрын шийдвэрийг эцэслэн батлахаас гадна гадаад хэргийн яамны ажилтан, албан тушаалтнуудыг томилдог. Сайд нь Парламентын гишүүний албыг давхар хашдаг тул ГХЯ-ны өдөр тутмын ажиллагаанд оролцох оролцоо нь хязгаарлагдмал байдаг бөгөөд түүний үйл ажиллагаанд дэмжлэг үзүүлэх зорилго бүхий “парламентийн орлогчид” ажилладаг. 2001 оноос эхлэн эдгээр орлогчдыг “төрийн нарийн бичгийн дарга” ба “парламентийн нарийн бичгийн дарга” хэмээн ангилах болжээ.

ГХЯ-нд 2 төрийн нарийн бичгийн дарга ажиллаж, сайдын эзгүйд шийдвэр гаргах ажиллагаанд оролцдог бол парламентын нарийн бичгийн даргаар 3 хүн ажиллаж, парламентын ажиллагаанд сайдыг төлөөлдөг.

ГХЯ-ны дотоод удирдлагад сайдын 1-р орлогч чухал үүрэгтэй ба энэхүҮ албан тушаалд мэргэжлийн дипломатч хүн томилогдож болдог. Сайдаар батлуулдаг бүхий л албаны асуудлууд түүний гараар дамждаг бөгөөд Сайд нарын танхимын нэгдсэн хуралдааны өмнө болдог 1-р орлогч сайд нарын хуралдаанд оролцож, засгийн газрын төслийг хэлэлцэх эрхтэй.

Гадаад бодлогын шийдвэр гаргалтад улс төр болон эдийн засгийн асуудал эрхэлсэн 2 орлогч сайд чухал байр суурьтай оролцдог.

ГХЯ-ны ерөнхий удирдлагатай холбоотой асуудлыг сайдын нарийн бичгийн даргын газар эрхэлдэг. Түүний бүтцэд боловсон хүчний хэлтэс, мэдээлэл харилцаа холбооны хэлтэс, нягтлан бодох бүртгэлийн хэлтэс, хилийн чанад дахь байгууллагуудын асуудал эрхлэх хэлтэс, хэвлэл мэдээлэл, олон нийттэй харилцах хэлтэс гэх мэт нэгжүүд багтдаг. Сайдын нарийн бичгийн даргын газар нь яамны тэргүүлэх газрын үүргийг гүйцэтгэдэг.

ГХЯ-ны бусад товчоо болон газрууд нь 2-дахь шатны бүтцийг бүрдүүлдэг ба тэдгээр нь газарзүйн болон тодорхой чиг үүргийн асуудлыг эрхлэн явуулдаг. Тухайлбал, Хойд Америкийн, Ази Номхон далайн, Латин Америк болон Карибын, Европын, Ойрхи Дорнод болон Африкийн гэсэн 5 газарзүйн товчоо, Гадаад бодлогын, Эдийн засгийн, Олон улсын хамтын ажиллагааны, Олон улсын эрх зүйн, Консулын, Тагнуул болон дүн шинжилгээний гэсэн тодорхой чиг үүрэг бүхий 6 товчоо, Ардын дипломат ажиллагааны, Зэвсэг хорогдуулах, цөмийн зэвсгийг үл дэлгэрүүлэх болон шинжлэх ухааны, Зүүн өмнөд ба Баруун өмнөд Азийн гэсэн төрөлжсөн чиг үүрэг бүхий 3 газар тус тус ажиллаж байна.

ГХЯ-ны 3-дахь шатны бүтцийг хэлтсүүд (70 орчим) бүрдүүлдэг бөгөөд тэдгээр нь тодорхой улсуудтай харилцах бодлого боловсруулах чиг үүрэгтэй ажилладаг.

ГХЯ-ны ажилтнуудын өдөр тутмын ажилд дараах үүрэг багтдаг. Үүнд :

-дипломат баримт бичиг орчуулах, боловсруулах асуудал

-ёслол хүндэтгэлийн асуудал

-гадаад улс орнуудын талаар мэдээлэл цуглуулах асуудал

-дипломатчдын уулзалтыг зохион байгуулах зэрэг асуудлууд орно.

2004 оны байдлаар Японы ГХЯ-ны нийт ажилтан, албан хаагчдын тоо 5000 гаруй байгаагаас 3000 орчим нь хилийн чанадад ажиллаж байна.

ГХЯ-ны ажилтнуудыг дипломат зэргээр ангилдаггүй, харин 3 бүлэгт хуваадаг. Дээд бүлгийн албан тушаалтнууд нь 1 ба 2-р шатны, дунд бүлгийн албан тушаалтнууд нь 3, 4, 5-р шатны, доод бүлгийн ажилтан, албан тушаалтнууд нь 6, 7, 8-р шатны зэрэгтэй. ГХЯ-нд шинээр ажилд орсон залуу дипломатчид 7, 8-р шатны зэрэгээс эхэлдэг бол ойролцоогоор 7 
жил ажиллаад 6-р шатны зэрэгт шилжиж, дахин 2 жил ажилласнаар 5 дугаар шатны зэрэгт хүрдэг.

Японы ГХЯ-нд ажилтан шалгаруулж авах явдал нь яамны төдийгүй төрийн албаны нэг томоохон асуудал болдог бөгөөд төрийн нэгдсэн шалгалтыг зохион байгуулсаны үндсэн дээр сонгон шалгаруулж авдаг. ГХЯ-нд ажилтнаар орохын тулд Кэйо, Токиогийн Их сургууль, Токиогийн Гадаад хэлний дээд сургууль зэрэг нэр хүндтэй их дээд сургуулийг төгссөн байхын зэрэгцээ, нийгмийн гарал үүслийн хувьд дээд давхаргынхан ялангуяа дипломат хүрээнийхнээс гаралтай байвал тухайн хүнд давуу байдлыг бий болгодог.

Дипломат албанд орох хүсэлтэй хүмүүсээс авах шалгалт нь 2 чиглэлээр явагддаг бөгөөд 1дэх нь дипломат ажилтнуудыг, 2-дахь нь ГХЯ-ны мэргэжилтэн буюу захиргаа техникийн ажилтнуудыг шалгаруулж авахад чиглэдэг. Нэр дэвшигчид албандаа орохдоо хатуу шалгалтаар ордог бөгөөд тэднээс Японы үндсэн хууль, Олон улсын эрх зүй, Гадаад хэл, 1870-аад оноос хойшхи Японы дипломатын түүх зэрэг шалгалт авдаг ажээ.

Японы дипломатчдын зарчим бол мэдлэгээ байнга нэмэгдүүлж байх явдал юм. Дэлхийн хэл болох англи хэлийг сурах нь дипломатчдын хувьд онцгой чухал гэж үздэг. Японы дипломат ажиллагааны нэг онцлог шинж бол дипломат албанд үе залгамжлах явдлыг нааштайгаар хүлээн зөвшөөрдөг явдал бөгөөд Японы дипломат албанд 3-дах болон 4-дэх үеийн дипломатчид цөөнгүй ажилладаг.

Японы ГХЯ-нд ажиллагсдыг дотоод хэлтсүүдийн хооронд шилжүүлэн ажиллуулдаг төдийгүй бусад яаманд ажиллуулан тэдний мэдлэг чадварыг дээшлүүлж байдаг. Тэр бүY хэл, төрийн бус байгууллагууд болон ГХЯ-ны ажилтнууд солигдон ажиллах тохиолдол байдаг. Японы ГХЯ нийт ажилтнуудын ур чадвар, мэдлэг боловсролыг дээшлүүлэхэд ихээхэн анхаарч, тэднийг дотоод, гадаадын тусгай курсүүдэд тодорхой хугацаанд суралцуулдаг байна.

Японы дипломат албанд ажиллагсдаас өдөр бүр хувийн цагаа умартаж, хүчээ бүрэн дайчлан, уйгагүй хичээллэхийг шаарддаг. Дипломат ажилтнуудын нийгмийн халамжийн асуудал ГХЯ-ны бас нэгэн томоохон шийдвэрлэж байх ёстой асуудал болдог. ГХЯ-аас дипломат ажилтнууд, тэдгээрийн гэр бүлийнхэнд тусгай мөнгөн урамшуулал, тээврийн болон эмчилгээний зардал, жилийн дунд болон эцэст нэмэлт цалин зэргийг олгодог. Японы боловсон хүчний агентлаг жил бүр төрийн албан хаагчид болон хувийн салбарт ажиллагсдын нийгмийн халамж, цалингийн харьцуулсан судалгааг хийдэг бөгөөд үүний үр дүнд цалингийн дундажийг нэмэх хуулийн төслийг парламентад өргөн барьдаг.

ГХЯ-нд дараах албан тушаалын бүтэц байдаг. Үүнд: - сайд, - сайдын 1-р орлогч, - орлогч сайд, - товчоо, газрын ерөнхий захирал, - ерөнхий захирлын орлогч, - хэлтсийн эрхлэгч, хэлтсийн эрхлэгчийн орлогч, - хэлтсийн эрхлэгчийн туслах, - хэлтсийн ажилтан гэсэн дараалалтай.

Японы хилийн чанад дахь дипломат албанд олон улсын жишгийн зэргийг баримталдаг бөгөөд эдгээр нь: - элчин сайд, - элчин зөвлөх, -зөвлөх, - 1, 2, 3-р нарийн бичиг, - атташе зэрэг болно. 
Эх сурвалж:

Ном сурах бичиг:

-Алиев Р.Ш. “Внешняя политика Японии в 70-х - начале 80-х годах” - М., 1986.

-М.Дүгэрсүрэн, О.Хосбаяр -“Дипломат ажиллагаа, дипломат албаны үндэс” УБ.1998 он

-Т.В. Зонова.“Дипломатия иностранных государств”. Москва. 2004 год

-Т.Намжим. “Япон орон: тоймлон харвал” . УБ. 1999 он

-"Nippon the land and its the people".Tokyo.1988

-В.В.Овчинников.“Сакура и дуб. Впечатления и размышления о японцах и англичанах”. М . 1971 год

-А.Н.Панов. “Японская дипломатическая служба". М. 1988 год

-В.И.Попов-“Орчин үеийн дипломат ажиллагаа” Москва. 2003 он

-Д.Цолмон. “Дипломат ёс горим, ёслол, баримт бичиг”.УБ.2006 он

-Д.Цолмон, Д.Оюунсүрэн, С.Баясгалан. "Гадаад бодлого, дипломат ажиллагаа, дипломат албаны үндэс" УБ. 2009 он.

Интернет эх сурвалж:

-www.kantei.go.jp

-www.historyworld.net/history of japan

-www.jica.go.jp

-www.mofa.go.jp

-www.wikipedia.org 